\title{
Punitive damages for breach of contract: what's so special about contract claims?
}

It might seem presumptuous for an English lawyer to talk to a Texas audience on the subject of punitive damages for breach of contract. The US literature is immense and has addressed the problem from almost every imaginable perspective. By contrast, there are no cases in England, and only a few elsewhere in the British Commonwealth, which have granted such relief at all.

On the other hand, this position does in practice provide the advantage of starting from a clean slate, without some of the intellectual baggage carried by the American case-law and commentary. Furthermore, from the point of view of comparative law the subject is very much a live one. It is true that civil lawyers in general ${ }^{1}$ are still a long way away from accepting the punitive principle in contract damages, or indeed at all ${ }^{2}$. But there are nevertheless civil law jurisdictions that do allow punitive damages ${ }^{3}$. Furthermore, even among those that do not - at least in theory - the flexibility of damages for non-pecuniary loss may well let in a more or less official practice of damages aimed at deterrence as well as compensation proper ${ }^{4}$. Added to this, the French institution of the astreinte, a kind of private fine against those who disobey court orders to fulfill their obligations ${ }^{5}$, has obvious affinities with punitive damages.

As for England, which used to be one of the most restrictive common law jurisdictions, the House of Lords has recently liberalized the rules so as to leave the question more open. Prior to 2002 punitive awards in England were deliberately marginalized; as a result of decisions in $1963{ }^{6}$ and $1971{ }^{7}$ (rightly described by one commentator as an "unfortunate experiment" ${ }^{8}$ ) they were limited to a few listed torts ${ }^{9}$. Furthermore, even within these they were restricted to cases where the tort either

\footnotetext{
${ }^{1}$ Including Louisianians, whose state law prohibits punitives except when specifically allowed by statute: Billiot v. British Petroleum Oil Co., 645 So. 2d 604, 612 (1994).

${ }^{2}$ Stoll, 11 Encyclopaedia of Comparative Law, §§ 104 et seq. France: Viney \& Jourdain, Les Effets de la Responsabilité (2d ed), §§ 4-6. For German law, see BGB, §§ 249-252, exhaustively defining damages in compensatory terms; also Behr, Punitive Damages in American and German Law Tendencies Toward Approximation of Apparently Irreconcilable Concepts, 78 Chi.-Kent L. Rev. 105 (2003). The theoretical objection to punitives in German law has been taken very seriously. It was held in 1992 to preclude enforcement of even foreign punitive awards on public policy grounds: see BGHZ $118,312$.

${ }^{3}$ Professor Gotanda cites Brazil, Israel, Norway, the Philippines, and Poland (Gotanda, Punitive Damages: A Comparative Analysis, 42 Colum. J. Transnat'l L. 391, 395) (though Israel is only arguably a civil law jurisdiction). The European Court of Justice has also said that damages for sex discrimination at work contrary to EU law must be sufficient not only to compensate but also to deter, which seems to mandate a punitive element in at least some cases: von Colson v. Land NordrheinWestfalen, [1986] 2 C.M.L.R. 430, 453-454.

${ }^{4}$ As where the German Supreme Court in 1961 condoned a deterrent element in damages for breach of privacy: see the decision at BGHZ 35, 363, cited in Behr, supra, at 133.

${ }^{5}$ Where the court order to perform is disobeyed the court has the power to set a fine (normally a daily or weekly one) as long as the disobedience continues, payable to the plaintiff. The subject is usefully summarized in Viney \& Jourdain, Les Effets de la Responsabilité (2d ed), § 6.5

${ }^{6}$ Rookes v Barnard [1964] A.C. 1129.

${ }^{7}$ Cassell \& Co Ltd v Broome [1972] A.C. 1027.

${ }^{8}$ See Partlett, Punitive Damages: Legal Hot Zones, 56 La. L. Rev. 781, 787 (1996).

${ }^{9}$ Which, significantly, did not include negligence in any form: AB v South West Water Services Ltd [1993] Q.B. 507.
} 
was committed by a government entity or employee, or - in the case of a private wrongdoer - was motivated by a calculation that the tort would result in a gain to the defendant exceeding any tort damages he might have to pay ${ }^{10}$. This obviously excluded punitive damages en bloc from the whole field of contract. However, in Kuddus v Leicestershire Chief Constable ${ }^{11}$ the House of Lords removed the first restriction. Furthermore, at least one member of the House cast considerable doubt on the second, on the understandable basis that the limitation contained in it served no discernible purpose except as an arbitrary way of showing disapproval of the whole idea of punitive damages ${ }^{12}$. Assuming that his view is followed (and this seems a racing certainty in the near future, at least if the matter reaches the House of Lords again), it follows that on principle there is now no absolute bar on punitive damages for breach of contract in private law ${ }^{13}$. Elsewhere in the British Commonwealth the extremely constricting English were never applied ${ }^{14}$, and hence the ground was more fertile to start with as regards contract actions. This has not gone unnoticed. While Australia has thus far refused to extend punitive damages outside tort cases ${ }^{15}$, the New Zealand High Court has been prepared to accept for the sake of argument that they can be awarded for breach of contract ${ }^{16}$, and in 2003 the Canadian Supreme Court explicitly, if controversially, gave punitive damages on a contract theory in a first-party insurance bad faith case ${ }^{17}$. Furthermore, although this is not strictly relevant to the breach of contract issue, it is worth noting that Canada and New Zealand, like many US jurisdictions ${ }^{18}$, have now firmly come down on the side of allowing punitive awards for other nontortious wrongs, such as breach of fiduciary duty ${ }^{19}$.

The thrust of this paper can be straightforwardly summarized in two propositions.

\footnotetext{
${ }^{10}$ For the history see generally Tettenborn, Punitive Damages - A View from England, 41 San Diego L. Rev. 1551, 1552 et seq (2004).

${ }^{11}$ [2002] 2 A.C. 122.

${ }^{12}$ See [2002] 2 A.C. 122, 145 (Lord Nicholls).

${ }^{13}$ Though perhaps not short of the House of Lords: see the comments in Travelers Casualty \& Surety Co of Europe Ltd $v$ Sun Life Assurance Co of Canada (UK) Ltd [2004] EWHC 1704 (Comm), [2004] Lloyd's Rep IR 846 at [76]. In one case, Newcastle upon Tyne CC v Allan [2005] I.C.R. 1170 they were refused in a statutory contract claim: but since the statute concerned pretty clearly was intended to exclude any non-pecuniary loss, this is arguably a special case.

${ }^{14}$ See Vorvis v Insurance Corporation of British Columbia (1989) 58 D.L.R. (4th) 193 (Canada); Uren v. John Fairfax \& Sons Pty. Ltd (1966) 117 C.L.R. 118 (affirmed in the Privy Council, [1969] 1 A.C. 590) (Australia); Taylor v. Beere [1982] 1 N.Z.L.R. 81 (New Zealand). The Republic of Ireland equally retained an expansive approach: Conway v. Irish National Teachers' Organisation [1991] 2 I.R. 305 (constitutional tort).

${ }^{15}$ See Gray v Motor Accident Commission (1998) 196 C.L.R. 1, 6-7; Hospitality Group Pty Ltd v Australian Rugby Union Ltd (2001) 110 F.C.R. 157 at [142]-[143], [164]; and more recently Harris $v$ Digital Pulse Pty Ltd (2002) 44 A.C.S.R. 390 (declining to extend punitive awards despite developments elsewhere in the Commonwealth).

${ }^{16}$ Gunton v Aviation Classics Ltd [2004] 3 N.Z.L.R. 836 (conduct by seller of unairworthy helicopter highly blameworthy, but not quite egregious enough for a punitive award). An award had actually been made in Tak and Co Inc v AEL Corporation Ltd (1995) 5 NZBLC 103, the correctness of which was left open in Gunton.

${ }^{17}$ Whiten v Pilot Insurance Co [2002] 1 S.C.R. 595: criticized in Swan, Punitive Damages for Breach of Contract: A Remedy in Search of a Justification, 29 Queen's L.J. 596 (2004).

${ }^{18}$ See, e.g., the decisions in Thyssen, Inc. v. S.S. Fortune Star, 777 F.2d 57, 63 (1985) and Airlines Reporting Corp'n. v. Aero Voyagers, Inc., 721 F. Supp. 579 (1989) (both applying NY law); and generally Sullivan, Punitive Damages in the Law of Contract: The Reality and the Illusion of Legal Change, 61 Minn. L. Rev. 207, 226-29 (1977).

${ }^{19}$ Canada: Norberg v. Wynrib [1992] 2 S.C.R. 226. New Zealand: Aquaculture Corp'n v New Zealand Green Mussel Co Ltd [1990] 3 N.Z.L.R. 299.
} 
(1) If we accept the principle of punitive damages in tort cases, their appropriateness in at least some suits for breach of contract cannot seriously be questioned. The issue is not so much whether punitive awards should be available for breach of contract, but when.

(2) Subject to one possible exception, there is no need for specific restrictions on their availability in breach of contract cases. It is true that there may be a commercial necessity to prevent every breach of contract suit from becoming a potential punitive damages claim: but this, I suggest, can be perfectly well satisfied by applying principles similar to those that already govern damages in torts.

Admittedly, the assumption in (1) is a big one, even though all but some five state jurisdictions accept it ${ }^{20}$. There are strong arguments against punitive damages anywhere as a matter of principle. It can, for instance, be argued that they confuse the functions of criminal and civil law and thereby violate due process in so far as they punish the defendant without providing criminal safeguards ${ }^{21}$ : that they reward handsomely the undeserving plaintiff ${ }^{22}$ : that they do not in fact deter defendants, or if they do they do it in an inefficient way: that they create unacceptable social costs, as by bankrupting otherwise economically viable defendants ${ }^{23}$ : and so on ${ }^{24}$. But this article is not the place to canvass these arguments. I will therefore assume the propriety of punitive awards as a matter of principle and concentrate on the specific point of whether, and if so when, their award is ever justifiable in a contractual setting.

\section{The point of principle: are punitive damages ever justified in contract suits?}

The American authority on whether a contract claimant can obtain punitive damages, and if so when, is substantial; it therefore forms an obvious starting-point for any discussion of the subject. But, if one may say so, it is not a very helpful one. To say the cases do not provide a uniform or clear rule is an understatement. It is true that most state courts pay at least lip-service to the proposition that prima facie there can be no punitive award for a breach of contract ${ }^{25}$. But then add to this continual

\footnotetext{
${ }^{20}$ The exceptions being the civilian Louisiana (see above) and Nebraska, Massachusetts, New Hampshire and Washington, all of which bar such damages as a common-law remedy. See Rustad \& Koenig, Taming the Tort Monster: The American Civil Justice System as a Battleground of Social Theory, 68 Brooklyn L. Rev. 1, 66 (2002).

${ }^{21} \mathrm{Cf}$ Owen, Punitive damages awards in product liability litigation: strong medicine or poison pill? 39 Vill. L. Rev. 363, 364 (1994). The point troubled Rehnquist J in Smith v. Wade, 461 U.S. 30, 59 (1983) and also Lord Devlin in the English decision in Rookes v Barnard [1964] A.C. 1129, 1230.

${ }^{22}$ See, e.g., Roginsky v. Richardson-Merrell, Inc., 378 F.2d 832, 841 (2d Cir. 1967); also Lord Devlin in Rookes $v$ Barnard [1964] A.C. 1129, 1230 ("I do not care for the idea that ... an aggrieved party should be able to inflict for his own benefit punishment by a method which denies to the offender the protection of the criminal law.") (italics added). The point is admittedly stronger in England than in the US, since in the US punitives can serve as a surrogate for recovery of attorney's fees, whereas in England the plaintiff gets these anyway as a matter of course.

${ }^{23}$ See Viscusi, The Social Costs of Punitive Damages Against Corporations in Environmental and Safety Torts, 87 Geo. L.J. 285 (1998).

${ }^{24}$ See e.g. Sales \& Cole, Punitive Damages: A Relic That Has Outlived Its Origins, 37 Vand. L. Rev. 1117 (1984). The arguments are well summarized in Beever, The Structure of Aggravated and Exemplary Damages, 23 Oxford J. Leg. St. 87 (2003).

${ }^{25}$ Farnsworth, Contracts, $\S 12.3$, at 157 (3d ed. 1999) ("Punitive damages should not be awarded for breach of contract because they will encourage performance when breach would be socially more
} 
disagreement about whether there can be exceptions (and if so, whether they apply to breaches of all contracts or only some kinds of contract) ${ }^{26}$; differing classifications of what actually counts as a contract claim for these purposes ${ }^{27}$; a collection of more or less explicit state statutes on the matter ${ }^{28}$ to be followed (or, if the court is sympathetic to the plaintiff, circumvented ${ }^{29}$ ); and the fact that an undue proportion of the authorities concern one kind of claim - insurance bad faith - which can amount to the legal tail wagging the juristic $\operatorname{dog}{ }^{30}$; and the difficulties become clear. In practice, however, some four broad trends are discernible ${ }^{31}$.

First, a good many states ${ }^{32}$ take the purist or traditional line. Distinguishing sharply tort and contract liability, they simply deny punitive damages in the latter, period. Damages of this sort are thus limited to cases where the plaintiff can prove some traditional independent tort, such as fraud, in addition to the breach of contract 33 .

Secondly, a few jurisdictions similarly exclude punitive breach of contract liability on principle, but then recharacterize certain contract claims - notably the duty of good faith implicit in most contractual obligations - as torts, which can then be made susceptible to a punitive award ${ }^{34}$.

Thirdly, yet others achieve much the same result by allowing punitive damage claims outside the tort arena, but strictly limiting them to certain types of contract. Common candidates are insurance contracts, those involving vulnerable groups or "special relationships," and those (for example, partnership) with fiduciary overtones ${ }^{35}$.

Lastly, a small number of states ${ }^{36}$ accept punitive damages as a possible remedy in contracts generally, and leave the limitations on such damages to be answered - as they are in torts - not by reference to any a priori rule, but by

desirable.")

${ }^{26}$ For a summary of the various positions, see Dodge, The case for punitive damages in contracts, 48 Duke L.J. 629, 637 (1999).

${ }^{27}$ Powers, The availability of tort remedies for breach of contract: border wars, 72 Tex. L. Rev. 1209 (1994).

${ }^{28}$ E.g. Cal. Civ. Code 3294(a); Mont. Code Ann. 27-1-220(2)(a); Nev. Rev. Stat. 42.005(1). All specifically prohibit punitive contract damages, though Montana has an exception for product liability and bad faith nonpayment (aimed, no doubt, at insurers).

${ }^{29} \mathrm{As}$ in (to take one example) the reclassification of insurance bad faith as a tort to get round a restrictive Montana statute: Lipinski v. Title Ins. Co., 655 P.2d 970, 977 (1982).

${ }^{30}$ The literature is large. See, e.g., Ashley, Bad Faith Liability, $\$ 2.05$ (1987); Graves, Bad-Faith Denial Of Insurance Claims, 65 Tul. L. Rev. 395, 402 (1990). For a strong criticism, see Gergen, Symposium on the law of bad faith in contract and insurance: I. The availability of tort remedies for breach of contract: A cautionary tale about contractual good faith in Texas, 72 Tex. L. Rev. 1235 (1994).

${ }^{31}$ See generally Dodge, The case for punitive damages in contracts, 48 Duke L.J. 629, 644 et seq (1999).

${ }^{32}$ Listed in Dodge, The case for punitive damages in contracts, 48 Duke L.J. 629, 644, n.87 (1999).

${ }^{33}$ For example, where a seller has not only supplied bad goods but in addition fraudulently miscertified them to the buyer, giving rise to rortious liability for fraud: $\mathrm{cf}$ the recent California decision in Robinson Helicopter Co., Inc. v. Dana Corp., 34 Cal. 4th 979; 102 P.3d 268 (2004).

${ }^{34}$ Notably Vermont and Hawaii: Dodge, The case for punitive damages in contracts, 48 Duke L.J. 629, 648-649 (1999). California takes a similar view: see e.g. Harris v. Atlantic Richfield Co., 14 Cal. App. 4th 70; 17 Cal. Rptr. 2D 649 (1993). The Canadian courts have laid themselves open to suspicion of doing the same thing: e.g., Prinzo v. Baycrest Centre for Geriatric Care (2002) 215 D.L.R. (4th) 31 (wrongful termination: tort claim for intentional infliction of emotional distress superadded to justify punitive award).

${ }_{35}$ Dodge, The case for punitive damages in contracts, 48 Duke L.J. 629, 646. The insurance exception can on occasion be statutory, as in (e.g.) Pennsylvania: see 42 Pa.C.S. § 8371.

${ }^{36}$ Notably Idaho, Mississippi, New Mexico and South Carolina: Dodge, The case for punitive damages in contracts, 48 Duke L.J. 629, 649. 
reference to specific criteria, such as the blameworthiness of the breach, the need for commercial certainty, and so on ${ }^{37}$.

Where does all this leave us? In discussing whether there is ever a justification for giving punitive damages in contract cases, we can, I suggest, start with two propositions.

The first is that torts and breaches of contract are analytically similar. Both are civil wrongs requiring the defendant to pay damages for infringing the plaintiff's rights, the only difference being the source of those rights. Now, if this is so, it is suggested that, prima facie, horizontal equity between plaintiffs must demand that they be treated in the same way as regards the rules relating to the kinds of damages that can be awarded ${ }^{38}$. Only if we can find some relevant difference in kind between the two types of damages claim - contract and tort, duties accepted and duties imposed - can we rationally justify allowing punitive awards in one but entirely disallowing them in the other. This is a point I return to later.

The second is that the question of punitive damages for breach of contract must be viewed as one of principle, rather than as an arbitrary exercise in classification. A given claim arising from breach of contract either should, or should not, be capable of giving rise to a penal award. In particular, this means that the second approach outlined above - arbitrarily moving some kinds of claim from the contracts course to the torts course - is unacceptable. Take a case where a defendant has clearly broken his contract willfully, outrageously and in bad faith - for example, a typical insurance bad faith claim. It solves no problems to reclassify the matter as a tort and then license a jury to mulct the defendant in punitive damages on that basis alone ${ }^{39}$. Whatever label a court chooses to attach to the claim, the complaint remains essentially one that the defendant has not done what he contracted to do, and the issue remains whether supracompensatory damages should be available. To create an artificial tort to cover the situation is simply an exercise in legal legerdemain, aimed at hiding a determination that breaches of contract of this sort ought to give rise to penal damages for some other unspecified reason, or possibly at circumventing a statutory prohibition of such damages in contract cases. If that determination falls to be made, it should be done openly on the basis of the policy factors involved.

Having cleared the air a little, is there then a relevant distinction of principle between tort and contract claims sufficient to justify treating the latter differently merely because they are contract claims? I suggest that there is not.

The first, and most important, point in this connection is based on consistency. Take some stock tort cases where awards of punitive damages are commonplace. A corporation peddles pills (or cars, or asbestos, or any number of other things that go to increase the hazards of twenty-first century life) that it knows to be potentially deadly; a rapacious lessor invades his tenant's home without color of right and throws her and her belongings in the street; an auto dealership makes a habit of deceiving consumers into buying substandard vehicles; and so on. Penal awards in cases such as these are routinely, and plausibly, defended on a number of

\footnotetext{
${ }^{37}$ See generally Atkinson v. Orkin Exterminating Co., 361 S.C. 156; 604 S.E.2d 385 (2004).

${ }^{38}$ A point rightly made in Bridgeman, Corrective Justice in Contract Law: Is There a Case for Punitive Damages? 56 Vand. L. Rev. 237 (2003). Cf Mather, Searching for the moral foundations of contract law, 47 Am. J. Jurispr. 71 (2002), arguing on this basis for a general punitive liability for all deliberate breaches. Note, however, that this seems a somewhat jejune approach, and this article does not go that far.

${ }^{39}$ See Powers, Symposium on the law of bad faith in contract and insurance: I. The availability of tort remedies for breach of contract: border wars, 72 Tex. L. Rev. 1209 (1994), $1230 \mathrm{n} 71$. This point has not gone unnoticed by some more sensible courts: see, e.g., Tobin v Ruman, 819 N.E.2d 78, 86 (2004) (no claim for punitives for failure to pay employee agreed compensation: allegation of fraud merely "repackaged version of his breach of contract claim").
} 
grounds. These include, among others, deterrence ${ }^{40}$; retribution ${ }^{41}$; the need to express curial disapproval and educate the public in the difference between acceptable and unacceptable behavior ${ }^{42}$; the inadequacy of compensatory damages in practice, and the desirability of funding the plaintiff's attorney fees to ensure she is not out of pocket ${ }^{43}$; and no doubt others. But, whatever the validity of these arguments, it is difficult to see why they should be regarded as peculiar to torts. On the contrary; very similar problems arise in contract suits; and I would suggest that the same logic is just as applicable there, assuming the breach is sufficiently outrageous and deserving of punishment ${ }^{44}$. Apart from the obvious example of the insurer stonewalling a known good claim in the hope that an impecunious client will give up in despair and go away, there are numerous other similar cases. Thus at one time or another particular courts have been prepared to countenance punitive awards against the home lessor who purposely omits to repair the property let, endangering the safety of the tenant (whom he dislikes and wishes to persuade to move anyway) 45; the contractor who deliberately retains payments due a cash-strapped subcontractor in order to force her to compromise a claim she has against him at a fraction of its value ${ }^{46}$; the business seller who blatantly and cynically breaks a noncompetition covenant, causing the bankruptcy of the buyer ${ }^{47}$; the lawyer who knowingly allows a conflict of interest to prevent his representing his client properly 48; and so on. The arguments in favor of deterring, or disapproving, conduct of this sort seem, at least at first sight, just as strong as those applying in the tort examples already mentioned.

And so, I suggest, with other arguments in favor of punitive awards, such as efficiency. It is difficult to deny that punitive damages are efficient in some tort cases $^{49}$ : in other words, there are at least some situations in which the possibility of a supracompensatory award will cause precautions to be taken whose costs are less

\footnotetext{
${ }^{40}$ See generally Restatement $2 d$ of Torts, § 908(1); Galligan, Augmented Awards: The Efficient Evolution of Punitive Damages, 51 La. L. Rev. 3, 6-14 (1990) (arguing that this is their sole legitimate aim). See too Owen, Punitive damages awards in product liability litigation: strong medicine or poison pill? A punitive damages overview: functions, problems and reform, 39 Vill. L. Rev. 363, 376377 (1994).

${ }^{41}$ Accepted as a possible aim, together with deterrence, in Galanter \& Luban, Poetic Justice: Punitive Damages and Legal Pluralism, 42 Am. U. L. Rev. 1393, 1432-40, 1447-51 (1993); see too Owen, Punitive Damages in Products Liability Litigation, 74 Mich. L. Rev. 1257, 1279 (1976).

${ }^{42}$ Owen, Punitive Damages in Products Liability Litigation, 74 Mich. L. Rev. 1257, 1281 (1976); Owen, Punitive damages awards in product liability litigation, 39 Vill. L. Rev. 363, 374-375 (1994).

${ }^{43}$ See Owen, Punitive damages awards in product liability litigation, 39 Vill. L. Rev. 363, 378 (1994) (and cf the Connecticut decision in Vogel v Sylvester, 174 A.2d 122 (1961)). This argument is urged specifically in connection with contract claims in Sebert, Punitive and nonpecuniary damages in actions based upon contract: toward achieving the objective of full compensation, 33 UCLA L. Rev. 1565 (1986).

${ }^{44}$ This is not of course to say that the criteria for an award of punitives should necessarily be the same: as we argue below, there may just be reasons for being more skeptical of punitive claims in contract than in tort. My argument is more limited: it is simply that there is no ground for excluding punitives as such in cases of breach of contract.

${ }^{45}$ E.g., Hilder v. St. Peter 144 Vt. 150, 478 A.2d 202 (1984); Young v. Scott, 108 Idaho 506, 700 P.2d 128 (1985) (both cases where punitives were awarded).

${ }^{46}$ E.g., Southern School Bldg., Inc. v. Loew Elec., Inc., 407 N.E.2d 240 (Ind. 1980).

${ }^{47}$ Compare Budget Rent-A-Car of Missouri, Inc. v. B \& G Rent-A-Car, Inc., 619 S.W.2d 832, 838 (Mo. 1981); Davis v. Gage, 106 Idaho 735, 682 P.2d 1282 (1984).

${ }^{48}$ Wilson v. Vanden Berg, 687 N.W.2d 575 (Iowa, 2004). See too the broker's churning case of Nunes v. Merrill Lynch, Pierce, Fenner \& Smith, 609 F. Supp. 1055 (D.C. Md. 1985) (where punitive damages would have been available had plaintiff proved malice).

${ }^{49}$ Though some have still done so: see, e.g., Viscusi, The Social Costs of Punitive Damages Against Corporations in Environmental and Safety Torts, 87 Geo. L.J. 285 (1998).
} 
than the costs that would have been incurred had the wrongful conduct taken place ${ }^{50}$. But then exactly the same argument applies in contract cases: whatever the position in contract as a whole, there are at least some breaches whose costs exceed their possible benefits to either party, and which are thus capable of being optimally prevented by the possibility of a penal award ${ }^{51}$. Similarly, much the same can be said of other, more tendentious and less mainstream, rationales for punitive damages, such as. arguments based on corrective justice ${ }^{52}$. The validity of justifications such as these may be open to question: but if one does accept them, there seems no $a$ priori reason for arbitrarily limiting their application to noncontract situations ${ }^{53}$.

Apart from consistency, the second reason for skepticism about any blanket exclusion of punitives from the contractual sphere is the sheer width of the spectrum covered by breach of contract claims. Given the variety of different kinds of contract claim, the idea that all of them share characteristics making punitives inappropriate seems inherently implausible. True, in theory all contract claims are bottomed on non-performance of some express or implied promise freely undertaken by the defendant rather than on some broad need for protection against unwarranted invasion of particular interests. But, as any contract lawyer can confirm, the reference to promise can be pretty remote and incidental. It is all very well to start from the contract theorist's favorite broken agreement to supply a quantity of disembodied widgets easily available in some elastic mythical market (no doubt administered from some faceless skyscraper in Chicago). Here there is indeed a very strong case for limiting the plaintiff to compensatories ${ }^{54}$. However, we have to note the limitations of examples of this sort. As pointed out below, they represent a rather specialised, almost mathematical, sort of contract. It follows that reasoning which is appropriate to them may be more difficult to apply to other contract-breakers. The opportunistic and cynical breaker of a noncompetition covenant, the seriously delinquent lessor, the supplier of consumer goods that he knows do not work and never will, and the professional guilty of outrageous malpractice, are all a long way from the staid commodity trader who fails to provide goods available elsewhere. In short, advocates of outlawing all punitive awards in contract cases have to produce convincing evidence that their arguments apply in all these nonstandard situations: and this is likely to be a tall order.

Thirdly, the idea that punitives should be excluded from contracts, while admitted in torts, necessarily presupposes a reasonably clear line between the two. Unless we are pretty certain just what claims we want to exclude punitive awards

\footnotetext{
${ }^{50}$ Among the large literature, the efficiency argument is nicely summarized in Polinsky \& Shavell, Punitive damages: an economic analysis, 111 Harv. L. Rev. 869 (1998). The argument there somewhat simplified - is that punitive damages should be based on computing the chances of the defendant escaping liability in some cases and increasing awards proportionately where he is sued to judgment.

${ }^{51}$ See, e.g., Perlstein, Crossing the Contract-Tort Boundary: An Economic Argument for the Imposition of Extracompensatory Damages for Opportunistic Breach of Contract, 58 Brook. L. Rev. 877, 879-90 (1992); Farber, Reassessing the Economic Efficiency of Compensatory Damages for Breach of Contract, 66 Va. L. Rev. 1443, 1448-62 (1980); Polinsky \& Shavell, Punitive Damages: An Economic Analysis, 111 Harv. L. Rev. 869, 936-39 (1998); Curtis, Note, Damage Measurements for Bad Faith Breach of Contract: An Economic Analysis, 39 Stan. L. Rev. 161, 166-70 (1986). Even Posner is driven to accept this: Economic Analysis of Law (6th ed. 2003), p.130, a point dealt with below. ${ }^{52}$ E.g. Mather, Searching for the moral foundations of contract law, 47 Am. J. Juris. 71 (2002); Bridgeman, Corrective Justice in Contract Law: Is There a Case for Punitive Damages? 56 Vand. L. Rev. 237 (2003).

${ }^{53}$ A point made in specific connection with corrective justice in Bridgeman, Corrective Justice in Contract Law: Is There a Case for Punitive Damages? 56 Vand. L. Rev. 237 (2003).

${ }^{54}$ Notably the efficiency argument that sellers should be encouraged to direct their wares to those who value them most and are thus prepared to pay most for them: Posner, Economic Analysis of Law (5th ed. 1998), p.142.
} 
from, the argument for doing so becomes distinctly shaky. In fact, however, even discounting cases where courts have artificially manufactured a cause of action in tort out of what is essentially a contract breach, this boundary is to say the least fuzzy. True, a simple case of nondelivery or nonacceptance in the sales context is contract or nothing: by contrast, a product liability suit by a worker injured by a lethally defective dumptruck must be tort. But other cases are not so easy. Take a client's malpractice suit against her lawyer (or other professional defendant). Does this count as contract or tort? In America the answer as often as not depends on where the plaintiff sues and what profession is involved ${ }^{55}$ : in England all client malpractice suits are contractual or tortious at plaintiff's option ${ }^{56}$ : and if one ranges abroad to France or Germany, the theory of liability is likely to be contract alone ${ }^{57}$. Similarly, if the malpractice plaintiff is a nonclient, the defendant's liability may again be contractual (depending on the generosity of the relevant jurisdiction as to contractual third party rights), or tortious, or both ${ }^{58}$. Yet again, take another fruitful field of litigation: imagine that a defendant terminates contractual negotiations pretextually and in incontrovertible bad faith, causing the plaintiff enormous and entirely foreseeable reliance losses. Assuming the defendant is liable for these losses at all ${ }^{59}$, the basis of liability is by no means clear-cut ${ }^{60}$. The US courts vary ${ }^{61}$ : it is possible to find theories of recovery based on contract ${ }^{62}$, estoppel ${ }^{63}$ and tort ${ }^{64}$. England, though disinclined to impose liability at all, would if it gave damages limit the plaintiff to tort ${ }^{65}$. Further afield, France imposes liability readily but does so in tort ${ }^{66}$; by contrast Germany, while emphatically willing to make the defendant liable in these circumstances ${ }^{67}$, is equally insistent on characterizing his liability as exclusively contractual ${ }^{68}$. In all these cases, the question whether the claim is

${ }^{55}$ Lawyers are generally liable in tort or contract alternatively: e.g. Collins v Reynard, 154 Ill 2d 48 (1992), Barcelo v. Elliot, 923 S.W.2d 575 (1995). Other professions have evoked a mixed response. Cf Congregation of the Passion v. Touche Ross \& Co., 159 Ill. 2d 137; 636 N.E.2d 503 (accountant liable in tort to client); Nielsen v US Automobile Ass 'n, 244 Ill App 3d 658, 612 NE 2d 526 (1993) (insurance agent's liability lies in contract); Moransais v. Heathman, 744 So. 2d 973 (Fla. 1999) (same with architect's liability to client). See generally Galligan, Contortions along the boundary between contracts and torts, 69 Tul. L. Rev. 457, 476 (1994).

${ }^{56}$ Henderson v Merrett Syndicates Ltd [1995] 2 A.C. 145.

${ }^{57}$ In France because of the rule of non-cumul, presumptively barring tort liability if there is a contract between plaintiff and defendant: Viney, IV Traité de Droit Civil, La Responsabilité: conditions, §§ 216 et seq.. On malpractice liability in Germany, see the accessible and readable Coester \& Markesinis,

Liability of Financial Experts in German and American Law: An Exercise in Comparative Methodology, 51 Am. J. Comp. L. 275, 278 (2003).

${ }^{58}$ Thus where an attorney negligently misdrafts a will and defeats a legacy, liability is normally predicated on tort, as in cases such as Biakanja $v$ Irving, 320 P.2d 16 (Cal. 1958)). But it may just as plausibly be bottomed on a third-party liability in contract: see, e.g. the Oregon decision in Hale $v$. Groce, 304 Ore. 281, 744 P.2d 1289 (1987).

${ }^{59}$ I discount here the possibility of recovery for benefits conferred, which is a different question essentially raising issues of restitution rather than damages.

${ }^{60}$ Cf Nedzel, A Comparative Study of Good Faith, Fair Dealing, and Precontractual Liability, 12 Tul. Eur. \& Civ. L.F. 97 (1997).

${ }^{61}$ See Farnsworth, Precontractual liability and preliminary agreements: fair dealing and failed negotiations, 87 Colum. L. Rev. 217 (1987).

${ }^{62}$ E.g., Drennan v. Star Paving Co., 51 Cal. 2d 409, 333 P.2d 757 (1958)

${ }^{63}$ Exemplified by Hoffman v. Red Owl Stores, 26 Wis. 2d 683, 133 N.W. 2d 267 (1965).

${ }^{64}$ Restatement $2 d$ of Torts, $\S \S 525,530$ (1977).

${ }^{65}$ The subject is nicely explored in Giliker, A Role For Tort In Pre-Contractual Negotiations? An Examination Of English, French, And Canadian Law (2003) 52 I.C.L.Q. 969.

${ }^{66}$ See the decision of the Cour de Cassation in 7 Apr 1998 D 1999.514, note P Chauvel; also Schmidt, La Sanction de la Faute Précontractuelle, 73 Revue Trimestrielle de Droit Civil 46, 51(1974).

${ }^{67}$ Cf now BGB, § 241.II, inserted in 2002.

${ }^{68}$ An example being the judgment of the Bundesgerichtshof dated July 14, 1967 by the. See too Lake, Letters of Intent: A Comparative Examination Under English, U.S., French, and West German Law, 18 
tortious or nontortious is answered essentially arbitrarily: but clearly, the policy issue of whether punitive awards should be available on a given set of facts remains the same.

Fourthly, it is worth remembering that in many, if not most, US jurisdictions (and occasionally elsewhere) punitive awards can be had for certain nontortious liabilities which do depend on an undertaking of responsibility, such as breach of fiduciary duty ${ }^{69}$. If this is right, then unless there is some particular feature about contract that marks it off from other damage liabilities, once again its exclusion is suspicious.

So far I have argued that contract and tort are similar in a number of ways that suggest they ought to be treated similarly. I now turn to the possible arguments that there is nevertheless a relevant difference in kind between them that justifies putting contract damages in a category of their own ${ }^{70}$.

One such argument is that tort claims differ in an essential respect from contractual ones in that tort duties are imposed for the benefit of all, willy-nilly the defendant, while contractual obligations are voluntarily accepted and are particular to the parties concerned. Hence (the argument continues) draconian discouragement of breach is much more important for the former than the latter ${ }^{71}$. But, whatever the instinctive attractiveness of this point, the closer we look at it the less substantial it becomes. Apart from the fuzziness of the contract-tort boundary itself, it is also the case that many tort duties are essentially undertaken rather than imposed: notable examples are those torts based on misrepresentation, such as negligent misstatement and (arguably) even fraud. Conversely, contractual duties - especially the ones where punitive damages are an issue - are often not that different from tortious ones, being in substance imposed rather than undertaken. There is little to choose in terms of voluntariness between the (contractual) duty of a lawyer not to engage in malpractice and the (tortious) obligation of a drug manufacturer not to peddle toxic pharmaceuticals: effectively both duties are imposed on a defendant simply by virtue of the business he practices. Again, once we get away from the archetypal contract to supply a quantity of easily-available widgets, breaches of contract may well affect nonparties in ways we ought to notice. It is easy to forget that it is not only the immediate parties who stand to lose from (for example) crass professional malpractice by lawyers and accountants, the continued and purposeful disregard of duties owed to consumers or small businesses; similarly, the market as a whole has an interest in preventing the cynical breach of noncompetition contracts by business sellers.

However, the most plausible ground for excluding punitive damages from contract liability, and the one that needs most argument to counter it, is that derived from efficient breach theory. It is limpidly summed up by Richard Posner. Suppose a manufacturer agrees to sell widgets to A. If, by breaching his contract with A and selling to B instead, he can make enough to compensate A for her loss and still come

\footnotetext{
Geo. Wash. J. Int'l L. \& Econ. 331, 351; Klein \& Bachechi, Precontractual liability and the duty of good faith negotiation in international transactions, 17 Hous. J. Int'1 L 1, 17 (1994).

${ }^{69}$ See the authorities referred to in Note 19 above.

${ }^{70} \mathrm{I}$ ignore arguments which, while addressed to contractual awards, are really attacks on the idea of punitive damages per se. A good example is Swan, Punitive Damages for Breach of Contract: A Remedy in Search of a Justification (2004) 29 Queen's L.J. 596. The invective here is directed specifically at the Canadian Supreme Court's acceptance of punitive damages in the insurance bad faith context in Whiten v. Pilot Ins. Co., (2002) 209 D.L.R. (4th) 257: but, as the author candidly admits, most of the points he makes are effectively arguments against the whole idea of punitives.

${ }^{71}$ An argument accepted, for instance, by the English Law Commission as justifying wholesale exclusion of contract punitives: see its Report No 247, Aggravated, Exemplary and Restitutionary Damages (1997), §5.72.
} 
out ahead, he should do so. The manufacturer is better off, $\mathrm{A}$ is no worse off, and the widgets end up with $B$, who values them most. However deliberate or shocking the manufacturer's breach, if we mulct him for extra damages we will likely "deter efficient ... breaches, by making the cost of the breach to the contract breaker greater than the cost of the breach to the victim." ${ }^{72}$ This argument has an instinctive plausibility and, no doubt for that reason, has since become pretty mainstream ${ }^{73}$. Nevertheless, it faces at least two major difficulties.

First, there is the obvious point that not all breaches of contract are efficient, even if the breaching party compensates the victim in full ${ }^{74}$. The widget example, for all its algebraic elegance (and its familiarity to law students and teachers alike), is atypical. It is much less clear how efficient breach applies to many of the contract breach cases we find in the real world: the car dealership from hell, the lawyer guilty of outrageous malpractice by subordinating the interest of one client to another, or the dishonest seller of a business who then opens up a competing outlet two doors away. Here, it is hard to see that anyone could seriously argue that there can be net social gains from the defendant's breach. Indeed, even Posner himself accepts a form of this point: he candidly admits that his arguments do not apply to at least some breaches, namely those that are opportunistic and merely filch value from a deserving to an undeserving party to the same contract ${ }^{75}$. And even with the widgets, the efficient breach theory is only a starting-point. When other costs associated with disruption, seeking alternative sources of supply, and so on are in account, this fast chips away at the efficiency of the breach, despite the neat figures we have become used to reading ${ }^{76}$.

Furthermore, it is not clear that the mere fact that a breach is efficient should necessarily preclude a punitive award anyway. As I observed above, deterrence is arguably not the only permissible aim of punitive damages: other objects, such as the need to express the disapproval of the court or to buttress public attitudes to antisocial behavior, may well be equally justifiable. Suppose a lawyer knowingly omits to represent his client's interests because another is prepared to pay more for his time: or a home inspection company purposely skimps on an inspection because it has better paying clients elsewhere. Even if this does effectively transfer a resource to a person who values it more than the other contracting party, this is not an attractive ground for exempting him from penal liability as a matter of principle ${ }^{77}$.

\footnotetext{
${ }^{72}$ Posner, Economic Analysis of Law (5th ed. 1998), p.142.

${ }^{73}$ Farnsworth adopted it in Farnsworth, Contracts, $\$ 12.3$, at 157 (2d ed. 1998) ("Punitive damages should not be awarded for breach of contract because they will encourage performance when breach would be socially more desirable."). It has also proved popular judicially (examples being Thyssen, Inc. v. SS Fortune Star, 777 F.2d 57, 63 (2d Cir. 1985) and Story v. City of Bozeman, 791 P.2d 767, 774 (Mont. 1990), and see too Judge Posner himself in Patton v. Md. Continent Systems, 841 F.2d 742 (7th Cir. 1988). For good measure the Law Commission in England also accepted efficient breach as a reason for recommending that punitives not be available for breach of contract at all: see Report No 247, Aggravated, Exemplary and Restitutionary Damages (1997), § 5.72.

${ }^{74}$ Friedmann, The Efficient Breach Fallacy, 18 J. Leg. St. 1.

${ }^{75}$ Posner, Economic Analysis of Law (5th ed. 1998), p.142. This qualification has been fairly widely accepted: e.g. Diamond, The Tort of Bad Faith Breach of Contract: When, If at All, Should It Be Extended Beyond Insurance Transactions?, 64 Marq. L. Rev. 425, 443-46 (1981); Perlstein, Crossing the Contract-Tort Boundary: An Economic Argument for the Imposition of Extracompensatory Damages for Opportunistic Breach of Contract, 58 Brook. L. Rev. 877, 879-90 (1992);Cohen, Reconstructing Breach of the Implied Covenant of Good Faith and Fair Dealing as a Tort, 73 Cal. L. Rev. 1291, 1302, 1309-10 (1985).

${ }^{76}$ See the remarks in Friedmann, The Efficient Breach Fallacy, 18 J. Legal Stud. 1, 7 (1989) and Macneil, Efficient Breach of Contract: Circles in the Sky, 68 Va. L. Rev. 947, 951-53 (1982); also the sour but perceptive remark of a Montana judge that efficient breaches are rarely efficient in fact (Story v. City of Bozeman, 791 P.2d 767, 774 (Mont. 1990)).

${ }^{77}$ See Dodge, The Case for Punitive Damages in Contracts, 48 Duke L.J. 629 (1999).
} 


\section{When should breaches of contract should be penalized?}

So far I have argued that there is nothing about contract claims that justifies a rule even a prima facie rule - ousting punitive awards. If this is right, the question comes down to this: assuming breaches of contract can attract punitives, which ones should? We can, I suggest, set aside one extreme position occasionally advanced: that is, that there is no reason not to penalize all breaches of contract, or at least all deliberate ones, on the basis that where such rights have been infringed corrective justice demands that the infringer give up any advantage gained as a result ${ }^{78}$. To begin with, this view logically applies to noncontractual causes of action as much as to contractual ones, and few if any would argue that all torts (or even all deliberate torts) should engender penal remedies as a matter of course. And in any case to say that the advantage gained from an infringement of the plaintiff's rights should be returned to the plaintiff is not so much an argument for punitive damages (which presumably would have to exceed those gains in order to be effective) rather than an argument for an extension of the law of unjust enrichment.

With this out of the way, the proper starting-point, it is suggested, follows from what we have already argued. If there is no bright line between contract and tort claims, and no reason to exclude punitives from contract claims as such, then the default position should be that the same criteria should be applied to breach of contract suits as to tortious ones. These criteria will obviously vary from jurisdiction to jurisdiction: but generally in tort punitives are a possibility where the defendant's conduct is oppressive, fraudulent or outrageous ${ }^{79}$ : that is, where he has acted in willful or reckless disregard of plaintiff's rights, or where his conduct exhibited some "evil motive or reckless indifference to the rights of others," ${ }^{80}$ and their award is necessary to punish the defendant and to deter him and others from doing the same thing in future ${ }^{81}$. American courts are more skeptical as to whether conduct falling short of intentional wrongdoing - crass or reckless negligence and the like - should attract punitive damages in tort ${ }^{82}$. But in as far as it does, then it should equally do so

\footnotetext{
${ }^{78}$ See, e.g., Mather, Searching for the moral foundations of contract law, 47 Am. J. Juris. 71 (2002).

${ }^{79}$ Restatement $2 d$ of Torts, § 908(1).

${ }^{80}$ E.g., Burnett v. Griffith, 769 S.W.2d 780, 789 (Mo. 1989). Conduct short of intentional wrongdoing may be sufficient to justify punitive damages in some jurisdictions. Courts use a variety of formulas to spell this out, including "reckless disregard for the rights of others," (Allman v. Bird, 353 P.2d 216

(Kan. 1960); or "willful misconduct, wantonness, recklessness, or want of care indicative of indifference to consequences," In re Air Crash Disaster Near Chicago, 644 F.2d 594 (7th Cir. 1981), cert. denied, 454 U.S. 878, 102 S. Ct. 358 (1981). Conduct that is merely negligent, even if it causes severe damage, is insufficient to justify punitive damages. This is usually held to be true of "grossly negligent" conduct when those terms are used as a synonym for "extreme carelessness" as opposed to "recklessness." Compare Moore v. Wilson, 20 S.W.2d 310 (Ark. 1929), with Williamson v. McKenna, 354 P.2d 56 (Or. 1960), suspersed by statute as stated in Winn v. Gilroy, 681 P.2d 776 (Or. 1984).

${ }^{81}$ Restatement 2 d of Torts, § 908, comment a; Cooper Indus., Inc. v. Leatherman Tool Group, Inc., 532 U.S. 424, 432 (2001)

${ }^{82}$ In most states it does not, but there are exceptions. See Blatt et al., Punitive Damages, A State by State Guide to Law and Practice, § 3.2 (1991 \& Supp. 1993); Partlett, Punitive Damages: Legal Hot Zones, 56 La. L. Rev. 781, 789 (1996); Prosser \& Keeton, Torts, 5th ed, 1984, § 2. The Restatement $2 d$ of Torts, $\S 908$, is to similar effect, demanding conduct that is "outrageous, because of the defendant's evil motive or his reckless indifference to the rights of others." The English Law Commission seems to agree, demanding a "deliberate and outrageous disregard of the plaintiff" s rights.": Law Commission Report No 247, Aggravated, Exemplary and Restitutionary Damages (1997), Draft Bill, s.3(6). But the position in other common law jurisdictions seems to be in favor of the possibility: e.g. Lamb v Cotogno (1987) 164 C.L.R. 1 (Australia), Robitaille v Vancouver Hockey Club Ltd (1981) 124 D.L.R. (4th) 228 (Canada), and more recently $A v$ Bottrill [2003] A.C. 449 (New Zealand).
} 
in contract. Indeed, there is much to be said for equiparating, say, a gross malpractice claim ${ }^{83}$ with a claim for very serious product liability negligence.

Does it follow from all this that - contrary to most lawyers' intuition, both in the US and elsewhere - punitive damages ought to be given as generously in contract cases as in tortious ones? Interestingly enough, I would suggest that in practice the answer is no, and that the effect of my recommendations is likely to be less marked than one might think. This is for two reasons. One lies in the inherent nature of contractual claims. The other arises from a suggestion I make below that the assimilation of contract to noncontract claims should be merely a default rule, applicable only in the absence of compelling arguments to the contrary: I will in factl argue that there is one case where, exceptionally, punitive damages for breach of contract should be excluded.

To begin with the first of these points, my suggestion is that, in the nature of things, it will often be more difficult in practice to demonstrate in a contract suit the necessary degree of outrageousness or reprehensibility, and with it the need to punish or deter the defendant.

Why? The first reason relates to a point is a fact already mentioned: namely, that breach of contract normally affects only the interests of the other parties to it, whereas a tort as often as not affects a much wider class. It is true (as I argued above) that the word "normally" matters: this is not invariably so and hence it is not an excuse to exclude contracts as a whole from the punitive damages regime. Nevertheless it remains the case that the number of persons affected by the defendant's wrong is a highly relevant factor: as courts and others have observed, the fact that the defendant's wrong was likely to have widespread effects is a strong indication in favor of making a penal award ${ }^{84}$. The converse also follows: the fewer people affected, the less appropriate punitive damages become.

Another important consideration is the type of damage involved. Of course some breaches of contract involve the creation of risks of personal injury or very serious property damage; nevertheless, torts are in the nature of things rather more likely to give rise to such risks. There is no doubt that the existence of risks of this sort is a powerful argument for punitive damages, since there is obviously a strong social interest in discouraging such behavior, and the creation of a danger to life is inherently more reprehensible than subjecting others to risks of mere economic losses ${ }^{85}$. By contrast, where there are no such risks, supercompensation is to that extent less justified ${ }^{86}$.

Furthermore, there is an interesting empirical distinction between typical cases of deliberate torts and knowing breaches of contract. Knowingly tortious behavior, or the commission of a tort comporting reckless disregard for the rights of others, is normally something for which it is difficult to find any convincing justification. An auto dealership will find it hard on any pretext to justify a habit of

\footnotetext{
${ }^{83}$ As in Bowman v Doherty, 686 P.2d 112 (Kan. 1984) (repeated failure of attorney to appear for criminal client). See too the surveyor's negligence case of A.B.C. Home \& Real Estate Inspection, Inc. v. Plummer, 500 N.E.2d 1257 (Ind 1986).

${ }^{84}$ E.g., see Boise Dodge, Inc. v. Clark, 453 P.2d 551, 557 (Id 1969) (punitive damages amply justified because of disregard of rights "not only of respondent ... but the consuming public generally." This is also the thrust of Polinsky \& Shavell, Punitive damages: an economic analysis, 111 Harv. L. Rev. 869 (1998), arguing that punitive damages are justified precisely because there are likely to be some victims who will not sue or recover.

${ }^{85}$ See, e.g., Schlueter \& Redden, Punitive Damages (3d ed. 1995), p.536. A few cases have made the distinction: e.g. Lightning v. Roadway Express, Inc., 60 F.3d 1551, 1559 (11th Cir. 1995) ("In determining the reasonableness of an award of punitive damages, courts should consider whether ... the misconduct caused personal injury or merely damage to property ....")

${ }^{86}$ And note that, even where punitives are awarded, an increased degree of danger to life and property justifies a higher award: BMW of N. Am., Inc. v. Gore, 116 S. Ct. 1589, 1599 (1996).
} 
lying to its customers; the same goes for the marketer of products showing reckless disregard as to whether they are likely to kill people, and to a large number of other tort defendants. On the other hand, the equities arising from breaches of contract, even deliberate ones, are a good deal less clear-cut. True, some such breaches are inexcusable on any normal reckoning. The seller of a business who contracts not to compete and then immediately and cynically poaches the buyer's entire customer base, and the crassly malpractising lawyer, are unsympathetic characters on any account. But most breach of contract is more nuanced: contracts are deliberately broken for all sorts of reasons, and with very varying degrees of culpability ${ }^{87}$. The interpretation of a contract may, for example, raise issues as to whether there is a breach at all, something that is not often in issue in a deliberate tort. Again, a contractor may be suffering from cash-flow or organizational problems, or shortages of labor or materials, that make it impossible for him to fulfill his obligations to some or all of his clients. In such cases, the breach may be deliberate (the defendant, after all, made a choice not to risk his solvency, or to perform his contract with $\mathrm{X}$ rather than $\mathrm{Y}$, and he could have chosen differently had he been so inclined). Nevertheless, in cases like these, where the choice to breach was, to say the least, constrained, the defendant's wrong is unlikely to be regarded as outrageous or reprehensible or a suitable subject for punitive damages.

Moreover, there is another point to remember about efficient breach. Despite the criticisms that can be advanced against the theory as a reason not to award punitive damages, it is pretty clear that if it does apply, it is more likely to do so in a contract than a tort suit. Although some deliberate torts are clearly susceptible to an efficient breach analysis (nuisance is an obvious example ${ }^{88}$, and there are no doubt others ${ }^{89}$ ), in the majority of cases deliberate torts are likely to be either inefficient per se, or opportunistic and thus outside the normal ambit of efficient breach anyway. In short, it remains true that it is easier to break a contractual than a tortious duty efficiently.

Now, the arguments just advanced go a good way toward calming fears of an explosion in contractual punitive damages suits even if, as I have argued, breaches of contract ought on principle to be treated the same way as torts. Many undeserving breach of contract plaintiffs will find themselves naturally, and rightly, excluded from a place at the punitive damages trough. Nevertheless, it has to be admitted that these considerations may not go quite far enough. The difficulties arise in particular in connection with typical commercial contracts. Here it has been argued, with some justification, that we should be wary of introducing punitive considerations: even if we do not wish to exclude them entirely, there is in most cases no reason to go beyond ordinary compensatory damages or to investigate the motives for breach ${ }^{90}$.

\footnotetext{
${ }^{87}$ See Pennington, Punitive Damages For Breach of Contract: A Core Sample From The Last Ten Years, 42 Ark. L. Rev. 31, 40 (1989). See too the interesting discussion, in the insurance context, in Capozzola, First-Party Bad Faith: The Search for a Uniform Standard of Culpability, 52 Hastings L. J. 181, 196 (2000); and more generally Cohen, The Fault Lines in Contract Damages, 80 Va. L. Rev. 1225 (1994).

${ }^{88}$ See Calabresi \& Melamed, Property Rules, Liability Rules, and Inalienability: One View of the Cathedral, 85 Harv. L. Rev. 1089 (1972) and the subsequent literature it has spawned.

${ }^{89}$ Including, perhaps, even conversion - at least on occasion. Suppose A, having agreed to supply B with a widget, finds that $\mathrm{C}$ is prepared to pay more for it, then all other things being equal $\mathrm{A}$ should sell it to $\mathrm{C}$ and leave $\mathrm{B}$ to her remedy in damages. It should clearly make no difference in this respect that ownership happens to have passed to B and hence A is technically liable in conversion as well as for breach of contract.

${ }^{90}$ A number of cases have made this point. See, e.g., Seaman's Direct Buying Serv., Inc. v. Standard Oil Co. of California., 129 Cal. App. 3d 416 (1982) (affirmed in part and reversed in part, 686 P.2d 1158 (1984)); see also Consolidated Data Terminals v. Applied Digital Data Sys., Inc., 708 F.2d 385 (9th Cir. 1983) (applying California law).
} 
Assume, for example, that a ship charterer breaks a charter for no reason other than that it is extremely unprofitable to it and it has a better use for its money (or for that matter that commercial relations have simply broken down); or conversely that a shipowner deliberately withdraws a ship half-way through a charter because it has another charterer prepared to pay a great deal more for it. Or imagine that a major bank, in breach of contract and with no other plausible excuse, withdraws from a syndicated loan agreement. The idea that conduct of this sort should engender claims for punitives as well as compensatory damages seems instinctively odd. But why? Of course in some such cases the question is straightforward on the arguments just advanced. For example, in a commercial as in a noncommercial contract, a defendant who fails to perform because of genuine cashflow difficulties is hardly deserving of punishment. Again, in a number of commercial situations there may be an argument based on efficient breach. The withdrawal of a ship under charter to take account of a better offer is simply the widget case writ large: all other things being equal, the resource (use of the ship) should be allowed to end up in the hands of the party that values it most. But this will not always be the case. Are there any other grounds for limiting punitive relief? Or, to put the question more bluntly, should there be a general "commercial contract exemption?"

This is certainly an intuitive idea, and one with some support: witness not infrequent suggestions that punitives in contract cases should be limited to contracts where there is some inequality, or dependence relationship, between the parties ${ }^{91}$. One can see the attraction of this view: if overreaching is a factor in favor of making a punitive award available, this ties in not only with a willingness to give punitive damages for analogous wrongs such as breach of fiduciary duty ${ }^{92}$, but also with the idea that punitives ought to protect the relatively powerless rather than those able to look after themselves ${ }^{93}$. But a blanket "commercial contract" limitation may be going too far. For example, take an egregious and deliberate breach of a construction contract between two medium-sized businesses, or a case where a bank deliberately withdraws funding facilities from a borrower in plain breach of contract and with no other plausible excuse. Or, for that matter, consider particularly gross malpractice by a law firm causing serious loss to a large client. There seems no reason why even large businesses should be denied the sanction of punitive damages on principle in such a case. On the contrary: many of the traditional arguments for punitives - such as the need to discourage such behavior and to protect the ethics of the marketplace continue to apply.

In situations of this sort there is, I suggest, room for a more sophisticated idea, which I put forward here in outline. Punitive awards should be denied in breach of contract cases, even where the breach is entirely deliberate, self-serving and unjustified, on one condition. This is that the defendant should be able to show that the act amounting to breach is one that, but for the fact that it infringed the plaintiff's rights, could be regarded as a reasonable business decision taken in good faith.

\footnotetext{
${ }^{91}$ E.g., Louderback \& Jurika, Standards for Limiting the Tort of Bad Faith Breach of Contract, 16 U.S.F. L. Rev. 187, 189 (1982).

${ }^{92}$ Supra, Note 17.

${ }^{93}$ See, e.g., Rustad \& Koenig, The historical continuity of punitive damages awards: reforming the tort reformers, 42 Am. U.L. Rev. 1269, 1332 (1993) ("The use of punitive damages by powerful corporations against their rivals is inconsistent with the traditional functions of the remedy .... Just as commercial law provides consumers with special protections that are not available to commercial concerns, it might be appropriate to limit punitive damages availability to relatively powerless individuals and entities."). Cf too Bridgeman, Corrective Justice in Contract Law: Is There a Case for Punitive Damages? 56 Vand. L. Rev. 237, 263 (2003), arguing that "sophisticated promisees should by now be on notice that in general promisors can breach freely and willfully as long as they pay expectation damages."
} 
Effectively this is sufficient to eliminate the specter of courts examining the circumstances of most ordinary breaches of commercial contracts, such as ship charters, distribution agreements and commodity supply contracts. The mere fact that a breach was self-serving and intended to increase the defendant's profits, or that it resulted from the defendant's desire to sever relations with the plaintiff, would thus be irrelevant. So also would be the knowledge that the breach might have disastrous consequences for the plaintiff's own business. In all these cases, there is a sensible commercial rationale for what the defendant did, even though in acting as it did it may have infringed the plaintiff's rights. In denying punitives in cases of this sort, we serve the important commercial interest that, when contracting, a contractor should be able to predict the "exit price" from the contractual obligation he has undertaken ${ }^{94}$. But where some other factor is present, such as a desire to harm the plaintiff without particularly benefiting himself or serving his own legitimate business interests, or a desire unfairly to further the interests of some third party or competitor of the plaintiff ${ }^{95}$, then the defendant's interest in foreseeing how much breach will cost becomes a great deal less defensible. The need to allow the defendant to exercise commercial judgement without the fear of open-ended liability in damages does not extend to decisions which serve no legitimate business or commercial end. protect the maker of commercial is virtually non-existent.

This solution also has a further advantage. The reasoning behind it can be extended to justify preserving the possibility of contractual punitive damages not only for deliberate and unjustifiable breaches, but also for egregious or gross negligence (for example, in professional malpractice claims brought by commercial entities). It is one thing to say - correctly - that malpractice liability is a risk run by any lawyer or accountant, and that the measure of any potential liability should thus be reasonably predictable. But this reasoning applies much less, if at all, to malpractice of such an outrageous nature that a court considers it worthy of punishment: this is not a normal business risk in respect of which there is a strong claim to protection.

\section{Conclusion}

The conclusion of this piece can be fairly briefly summed up in four propositions. (1) There is no justification for excluding punitive awards from contract damages as such. (2) On the contrary, breach of contract should generally be capable of giving rise to punitive damages on much the same basis as claims in tort. (3) In practice, a rule of this sort would, perhaps surprisingly, not give rise to an explosion in punitive claims against contract defendants. (4) Nevertheless, there is scope for one limitation in contract punitives, namely that a defendant should be able to escape them in so far as the breach amounted to a legitimate business decision independent of its wrongful nature.

\section{(C) Andrew Tettenborn 2005.}

\footnotetext{
${ }^{94}$ See Johnson, The Boundaries of Extracompensatory Relief for Abusive Breach of Contract, 33 Conn. L. Rev. 181, 182 (2000).

${ }^{95}$ For a straightforward example, see Pace \& Sons, Inc. v. Travelers Indemnity Co., 514 A.2d 766 (Conn, 1986) (insurance company withdrew surety bond from contractor because, among other things, it was "going to get" contractor).
} 